\title{
Russian Intelligentsia in the Age of Counterperestroika
}

Dmitri N. Shalin

University of Nevada, Las Vegas, shalin@unlv.nevada.edu

Follow this and additional works at: https://digitalscholarship.unlv.edu/sociology_pubs

Part of the International and Intercultural Communication Commons

\section{Repository Citation}

Shalin, D. N. (2018). Russian Intelligentsia in the Age of Counterperestroika. Russian Journal of Communication 1-13.

http://dx.doi.org/10.1080/19409419.2018.1518153

This Article is protected by copyright and/or related rights. It has been brought to you by Digital Scholarship@UNLV with permission from the rights-holder(s). You are free to use this Article in any way that is permitted by the copyright and related rights legislation that applies to your use. For other uses you need to obtain permission from the rights-holder(s) directly, unless additional rights are indicated by a Creative Commons license in the record and/ or on the work itself.

This Article has been accepted for inclusion in Sociology Faculty Publications by an authorized administrator of Digital Scholarship@UNLV. For more information, please contact digitalscholarship@unlv.edu. 


\title{
Russian Intelligentsia in the Age of Counterperestroika*
}

\author{
By Dmitri N. Shalin
}

*Dmitri N. Shalin is professor of sociology, director of the UNLV Center for Democratic Culture, coordinator of Justice \& Democracy Forum series, editor of the Social Health of Nevada Report, co-director of the International Biography Initiative, Erving Goffman Archives, and Russian Culture and Intelligentsia projects. His research interests and publications are in the areas of pragmatism, sociological theory, democratic culture and Russian society. 


\section{Russian Intelligentsia in the Age of Counterperestroika}

In 57 B.C.E., Marcus Tullius Cicero, a Roman consul and leading public intellectual, ran into heavy political headwinds. After turning down Caesar's invitation to join the antirepublican forces, he was driven into exile where he brooded about the duty he owed to himself, his family and his country.

In a letter to his friend Atticus, Cicero outlined the stark moral choices committed citizens face when the fate of the republic hangs in the balance. The question is "Whether one should remain in one's country, even under a tyranny. Whether any means are lawful to abolish a tyranny, even if they endanger the existence of the State. Whether one ought to take care that one who tries to abolish it may not rise too high himself. Whether one ought to assist one's country, when under a tyranny, by seizing the opportunities and by arguments rather than by war ... Whether one who has done good service for his country, and by it won ill-treatment and envy, should voluntarily put himself into danger for that country, or may at length take thought for himself and his dear ones and avoid struggles against the powers that be." (Cicero, 49B.C.E./1913, pp. 187-189)

Caesar's Rome and Putin's Russia are vastly different polities, yet the dilemmas Russian intellectuals and political activists face nowadays bear more than a fleeting resemblance to those that ultimately cost Cicero his life.

Ever since the collapse of the Soviet Union, emigration has been on its citizens' minds. An estimated 10 million Russians left the country since the mid-1990s. What is intriguing about the latest wave is the number of highly educated professionals heading for the door. Reliable data is hard to come by but the state agency Rosstat reports that some 350,000 Russians left the country in 2015, with educated, highly skilled workers leading the way. More recent figures are not available, but the trend appears to continue unabated. The migratory mood is particularly strong among the younger generation. The survey conducted by the Levada Center in May 2017 found nearly one third of respondents in the 18-24 age group seriously thinking about emigration - fifty percent more than three years earlier (Emigratsionnye nastroenia, 2017).

The process started in 2012 when Putin returned to power following the controversial presidential election. It accelerated after Russia invaded Ukraine in 2014 and counterperestroika gathered momentum, with the parliament passing a series of legislative acts that curtailed civil liberties and unleashed reprisals against the regime's opponents.

While some intellectuals went into voluntarily exile, others explored opportunities for resistance, still others sided with the regime. The ensuing debate split the Russian intelligentsia into factions whose members' violent disagreements bespeak a profound fissure not likely to heal anytime soon. 
Meet the famous movie-maker Andrei Konchalovsky. In 2016, the Venice Film Festival awarded Konchalovsky the Silver Lion prize for directing the film "Paradise," later nominated for an Oscar in the best foreign movie category. In a recent interview, he shocked his colleagues by lavishing praise on Vladimir Putin and repenting for being "blinded by the illusion that Russia shares its destiny with the West." The West rejected the Russian leader because "it wants to see us impotent, just as we were during perestroika. Thank God, we didn't make much progress along this path," bristled Konchalovsky, "for Europe is clearly facing a catastrophe. It is hubris to treat human rights as a paramount value.” (Konchalovsky, 2016)

Konchalovsky went on to commend the Soviet regime for imposing censorship and buffeting the creative class, the policy he credits for that era's enduring artistic achievements. "Censorship has never impeded creativity," declared the renowned director. "Cervantes created his masterpiece during the Inquisition. Chekhov expressed in his prose what he couldn't in his plays. Do you think freedom is necessary for creativity? Not at all - masterpieces are a product of constraints” (Ibid.).

Tatyana Tolstaya, one of Russia's premier writers, lived and taught for ten years in the U.S. where her son resides. Tolstaya is more circumspect in her praises of Putin and she refrains from passing judgment on the Ukrainian incursion, yet she commends Konchalovsky on his willingness to reevaluate the liberal values of his youth. The tone she struck in berating perestroika and attacking the West is every bit as nationalistic. "America wants to be number one in everything, it can't stand the fact that Russia occupies so much space on the globe," charged Tolstaya (2017) in an interview that made some of her admirers wince. Foolish Yeltsin heeded the advice of his foreign benefactors, but as soon as Russia ceased to be a threat, the West "promptly lost interest and left us dying in the ditch" (Ibid.).

Yunna Moritz, Nikita Mikhalkov, Oleg Tabakov, Aleksei Batalov - scores of iconic figures in the Russian beau monde cheered the annexation of Crimea. The feelings they expressed in heated polemics evince prejudice unthinkable in the past. "They are pathetic in some sense," fumes the stage director Oleg Tabakov (2015) about Ukrainians whom he blames for the bloody conflict with Russia. Adding insult to injury, he sneers, "In the best of times their literary and intellectual luminaries were second or third-rate compared to their Russian counterparts.”

On March 11, 2014 (Kollektivnoe obrashchenie, 2014), several hundred prominent artists and cultural figures signed a letter supporting the Russian Federation's policies in Ukraine. Many more concurred, privately and publicly, shedding light on the current nationalist frenzy.

Yunna Moritz (2014) used to irk the Soviet ideologues with her nonconformist poetry. Now she is leading the cheer for the invasion of Ukraine. "What we witness in Ukraine is an advent of the 'world order' that disguises fascism as national liberation struggle, that scorches human beings alive and destroys peaceful people." The sanctions the West imposed on Russia is the product of "russophobia," charges Moritz. Apparently, she acts on conviction, as her progovernment stance brought her no favor from the administration. 
Nikita Mikhalkov is a different story. A movie director, popular actor and TV star, this gadfly hails the government's farsighted policies with relish and profit. A film about Putin directed by Mikhalkov leaves no doubt about his reverent attitude toward the national leader. But then, Mikhalkov was equally effusive about Putin's predecessor, Boris Yelstin, befriending his family members, taking government money for his projects, vigorously campaigning for Boris Berezovksy, Yeltsin’s protégé, whom Putin would later run out of the country. Now Mikhalkov calls Yeltsin a "traitor" and wants to put him on trial, along with the father of perestroika Mikhail Gorbachev. Trumpeting the superiority of Russian values, Mikhalkov calls to clamp down on Western liberalism and its champions in Russia - "the fifth column" as it is referred to these days. Not surprisingly, the Union of Cinema Workers over which Mikhalkov presides enjoys generous government support.

Oleg Tabakov's talents as movie and stage actor are matched by his political savvy. His willingness to associate himself with the official policies, Tabakov confessed, is tied to his responsibilities as director of the Moscow Art Theater. By endorsing the Kremlin's actions, he was able to ensure a continued infusion of state funds into this venerable institution with its sizeable performance team. Tabakov's condescension toward Ukrainian culture, however, doesn’t appear to reflect any pragmatic consideration.

Chulpan Khamatova didn't sign the letter slamming the Ukrainian bid for independence, though she agreed to appear in Putin's promotional video. It so happens that Khamatova heads the children's health charity, Gift of Life, that draws its finances chiefly from the state, and that helped save many lives. Reports circulating after she agreed to become Putin's personal representative hinted at the moral quandary - support Vladimir Putin or see her charity's funds dry up.

Dead figures from Russia's illustrious past are enlisted in today's culture wars. The Nobel Prize winner Joseph Brodsky, once expelled from the Soviet Union for his unorthodox poetry, is being touted by the far-right nationalists as a Russian patriot. Had he lived long enough (Brodsky died in 1996), he would have hailed the annexation of Crimea, insist his conservative admirers. To buttress their case, nationalists cite Brodsky's verse about the 1991 referendum that sealed Ukraine's independence (Brodsky, 1994). In this rather vitriolic piece Brodsky mocked the Ukrainian yearning for independence and bade the neighbors a sarcastic farewell, using an ethnic slur (khokhly). One could shrug off this appropriation as far-fetched, but it is harder to dismiss Evgeny Rein, Brodsky’s friend, who added fuel to the fire by vouching that Brodsky told him personally, "Crimea must belong to Russia.” (Rein, 2015)

Virulent nationalism, rampant anti-Americanism, attacks on “Gayropa” (Gay Europe) are staples in Russia's public discourse. The West is blamed for the breakup of the Soviet Union, the hardship following the economic sanctions, the spiritual pollution of youth, and a multitude of other privations and indignities. To the liberal ideals rooted in Western culture, nationalists juxtapose the indigenous Russian values revolving around the $19^{\text {th }}$ century Tsarist mantra "autocracy, orthodoxy, populism." Variations on this slogan have come into vogue since Putin came to power in 2000. Autocratic rule is now firmly ensconced in the Russian Federation. Religious culture classes are mandatory in middle school. And endless talk about Russian spirituality (dukhovnye skrepy) inundates the state-controlled TV. 
The resentment feeding nationalist sentiments is easy to understand. It is familiar to people steeped in an imperial ethos and nursing a wounded pride after their empire collapsed. Vladimir Putin is admired because he beat back the secessionist movements threatening to shrink Russia to the Kingdom of Muscovy and Duchy of St. Petersburg. His tough rhetoric against the West ignoring Russia's interests as a world power and the NATO forces deployed ever closer to the nation's borders resonated with the citizenry demoralized by the collapse of the U.S.S.R. With the sovereignty over Crimea restored, the Russian national pride surged while patriotic movements of every stripe sprouted around the country. Add to this a steady growth in personal income fueled by high oil prices that produced the unprecedented level of prosperity in Russia, and you can see why over eighty percent of Putin's compatriots give their leader high marks.

Not all intellectuals feel nostalgic for the lost empire. Andrei Zviagintsev, Lyudmila Ulitskaia, Yuri Shevchuk, Andrei Makarevich, Marietta Chudakova, and their liberal comrades rose to condemn Russia's creeping imperialism. Members of the Russian Academy of Sciences, Cinema Union, Pen-Club, and kindred organizations drafted letters demanding the end of the occupation and decrying the wave of intolerance choking the nation.

“Our country has embarked on a dangerous adventure,” reads the March 13, 2014, proclamation issued by the organizers of the Congress of Intelligentsia in Opposition to the War.

Ignoring the principles of international law and European security agreements, Russia is careening toward another Cold War with an unpredictable outcome. Lies and disinformation are flooding the mass media, the vicious propaganda campaign is waged against everyone who doubts the legitimacy of the official course of action and points to the dire consequences awaiting the country. Everyone who dares to differ is branded as 'the fifth column' and labeled 'fascist.' (Obrashchenie initsiativnoi gruppy, 2014)

Liberal opponents of the invasion come from the same top tier of the Russian cultural elite, although their fortunes follow a different trajectory, reminding us what it's like to fight the authoritarian regime from within. Putin has been tightening control over civil society for years; the wave of poplar support he is riding after the Ukrainian invasion emboldened his followers to use extralegal means against the opposition. Now progovernment thugs intimidate dissidents with impunity.

Sociologist and political activist Leonid Gozman ended up with a broken arm after the police roughed him up during an anti-Putin demonstration. Last December, official patriots staged an exhibition designed to expose "national traitors" defaming Russian military history. At the entrance, nationalists had the names of Gozman, Goebbels and Hitler emblazoned on the museum floor, inviting visitors to trample on "the fascist monsters." After a public outcry, the authorities closed the exhibition without taking any action against those who defamed Gozman.

Patriotic brutes harassed journalist Oleg Kashin. His campaign to save the forest marked for extinction to make room for a highway cost him several broken limbs and a long stay in the 
hospital. Viktor Shenderovich, a popular writer and outspoken critic of Putin, was assaulted in public for his antigovernment opinions. The towering man who roughed him up threatened to do more harm if Shenderovich persisted in his antipatriotic opinions. Having learned the identity of the complainant, the police refused to pursue the case.

Liberal intellectuals wading into politics now expect to be pelted with rotten eggs, smothered with feces, or in the lucky case of Mikhail Kasyanov, with a tort. Lyudmila Ulitskaia was doused with a pungent liquid while handing out prizes to high schoolers competing for best history essays. Aleksei Navalny, a vocal opponent of Putin, was less fortunate - after acid was poured on his face, he lost eighty percent of sight in his right eye.

Struck by the fact that so many educated, gifted people are falling prey to state propaganda, Vladimir Nazarov implored his colleagues, 'What do you mean 'Crimea is ours,' since when is stealing from your neighbor OK? What about the Budapest memorandum we signed guaranteeing our neighbor's security?” (Nazarov, 2015). The Russian culture minister warned Nazarov, then a director of the acclaimed State Musical Theater, that unless he keeps out of politics, his theater would lose funding. Nazarov refused to shut up, and the institution he directed since 2002 had to close its doors.

The last case is symptomatic of government tactics aimed to deprive liberal institutions of their organizational and financial resources. We can see this in the recent drive to place the nongovernment organizations dedicated to human rights monitoring, independent research, and charitable work on the registry of "foreign agents." If upheld by the courts, this designation would make impossible the work of the Levada Center, Memorial Foundation, and other NGOs with ties to kindred organizations aboard.

The situation is equally precarious for the institutions that depend on state funding and that open themselves to hostile takeovers if they fail to follow the official line. That's what happened to the Film Makers' Union. At the end of Putin's second presidential term, the rank and file members elected mostly liberal officers, after which Nikita Mikhalkov went to court to invalidate the election results. Having secured a favorable verdict, he staged a new vote that kept his supporters in power in violation of the union charter. Film union members who challenged Mikhalkov faced reprisals. The Art of Cinema magazine was evicted from its headquarters after Daniil Dondurei, the publication editor, confronted the bully. Now Russia has two film-makers unions, one headed by Mikhalkov and supported by the state, the other run by the dissidents struggling to keep their institution afloat.

A similar fissure split the ranks of Russian sociologists. In April of 2011, the National Society of Sociologists lead by the internationally recognized authority Vladimir Yadov was challenged by the upstart Russian Sociological Association organized by Gennady Osipov, a conservative scholar and administrator with close ties to the Russian Orthodox Church (the Russian patriarch was inducted as an honorary member in the newly founded organization). The rival sociological associations ran separate annual meetings, elected two sets of officers, and went their separate ways, although the conservative association secured a certificate as "the only legitimate national and international representative of sociological science in the country." (Yadov, 2011) 
The fate that befell the Russian Academy of Sciences is another striking indicator of the changing political climate. Since the Soviet era, distinguished scholars comprising this hallowed institution elected their own officers, including the Academy's president. Now the Russian parliament is about to pass a law stripping academicians of the right to elect their president and limiting their ability to form governing bodies. If the law passes, all they can do is propose candidates for the top office, which will be appointed - or removed - by presidential decree. The key reason behind this law is the choice real estate controlled by the Academy and coveted by the Kremlin-sponsored investors like Mikhail Kovalchuk. A close friend of Putin, Mr. Kovalchuk several times sought to become a full member, which would have given him a shot at becoming president of the Academy. Having failed to secure the vote, he swore revenge: "If the Academy doesn't need me, I see no need for having such an Academy," he reportedly said after learning about the election results. Or so goes the rumor widely-circulated among Academy members.

To say that the lines of communication between competing factions of the Russian intelligentsia are strained would be an understatement. Invectives flying across the political divide keep stoking the enmity, opening old wounds all too familiar to the veterans of the intelligentsia's ideological battles (Shalin, 1989, 1990, 1993, 1996a, 1996b). There isn't much unity inside either camp. While Russian nationalists are vying with each other for the purity of their spirituality and the stringency of the measures to hold down the opposition, liberals debate whether cooperation with the government is advisable and where to draw the line between pragmatic compromise and selling out.

Is the chance to secure state funding for a worthy project reason enough to overlook violations of human rights? Should an outspoken director have heeded the warning to stay quiet rather than risk the future of a collective enterprise? Does the prospect of helping sick children justify backing a president whose policies you abhor? And should liberals work in governmentsponsored institutions where they can voice their critical views?

Shrewdly, Putin seeks to recruit nonconformist celebrities into state-sponsored public organizations like the Presidential Council on Human Rights, Culture Ministry Public Council, Interethnic Relations Board. The fact that the Russian culture minister Vladimir Medisnky is notorious for his illiberal views did not deter Iosif Bakhstein from joining his advisory board. He did so under the Soviets, explained Bakhstein, and saw no reason to shun cooperation with the current authorities. “As long as I can get state funding for my projects," I am OK with that. Besides, working with state bureaucrats offers an opportunity to educate them and thereby contribute to "building civil society in our country."

Daniil Dondurei accepted an invitation to join the council advising the president on human rights on the assumption that voicing his concerns at board meetings might persuade state officials to correct their policies. The Council, he pointed out, initiated inquiries into human rights abuses that lead to improvement in prison conditions. Even when his views were ignored, articulating them served a purpose. Calling his position "realistic" and "practical," Dondurei 
contrasted it to the unproductive "maximalism" of those who shun dialogue with the government (Dondurei, 2012).

Valeria Novodvorskaya, a fierce critic of Putin's regime who recently passed away, brushed aside such arguments as misguided and self-serving. Drawing a historical analogy, she pointed out that Leni Riefenstahl might have thought she was serving high modernist culture while shooting films about the Third Reich, but her products helped shore up Hitler's power. "The artists cultivated and promoted by Iosif Vissarionovich Stalin - ballerinas, singers, stage directors - soothed their conscience with the same arguments. What the intelligentsia helped secure was not the triumph of culture and popular will but the stabilization of the damned Soviet and Nazi regimes made of the same clothes” (Novodvorskaya, 2014). Novodvorskaya condemned collaborators like Yunna Moritz and Oleg Tabakov whose earlier achievements, she insisted, were forever compromised by their defense of the Crimean takeover. Russian intellectuals lending their talents to the repressive regime do little more than sully their names without softening the ugly realities of Putin's reign.

One person whose voice stands out in this clamorous debate is Viktor Shenderovich, an avowed liberal whose widely watched program of biting political satire was phased out under Putin. Shenderovich cautions his colleagues to stay true to the paramount values of tolerance and compassion. Yes, Yunna Moritz's defense of the Ukrainian invasion is indefensible, her views must be confronted head-on, but her position is sincere, she is no opportunist eager to flatter extant powers, and the fact that she succumbed to the national psychosis should not negate the outstanding contributions she made in the past. Chulpan Khamatova knows which personal sacrifices she had to make to get another children's hospital built, while her liberal critics entertain themselves with broadsides against the government. "The style of polemics is more important than its substance,” reminds Shenderovich his colleagues in a widely-discussed blog post made on June 20 (Shenderovich, 2017). “An intelligent attitude (intelligentsnost) implies not only firm convictions but - simultaneously and necessarily - the ability to take the role of the other. Otherwise, it is not intelligentnost but hardheartedness in its deadly form practiced by communists."

The battle lines are drawn within the ranks of Russian intelligentsia, a high-culturalcapital stratum of scholars, artists, educators and other publicly engaged intellectuals claiming a special role as guardians of national interests and harbingers of the future (Shalin, 1996a; Kochetkova, 2010).

Right or wrong, this is our country, the nationalists contend, and we must defend it against our enemies eager to dismember Russia and weaken us through economic sanctions. It is every citizen's duty to support the national leader in this time of need, to combat the fifth column undermining the nation's resolve and polluting Russian values.

The true patriot, liberals counter, is someone willing to confront the forces of intolerance and imperialism. Russia's destiny is with the West, with the liberal values that demand respect for international boarders, human rights and democracy. To support the government's repressive policies is to betray the Russian intelligentsia's tradition of speaking truth to power. 
One more principled stance is available to critics of a regime slouching toward dictatorship. To cite Cicero again, we must ask ourselves "Whether one is doing one's duty to the State, if one retires to some other place and there remains inactive, when there is a tyranny; or whether one ought to run every risk for liberty" (Cicero, 49B.C.E./1913, p. 189). More and more Russian intellectuals find the rationale for leaving the country compelling.

Surveys conducted by the Levada Center (2014, 2015, 2016, 2017) in the last few years show that the proportion of Russian citizens contemplating this option has grown since the invasion of Ukraine. In 2015, 5\% of the respondents indicated they were serious about emigration, $8 \%$ would leave given the opportunity, $15 \%$ of those with college degrees were prepared to depart, with the count of emigration-minded rising to $18 \%$ in large metropolitan areas. The young and educated are especially eager to explore the emigration option, 32\% according to the latest poll. Actual numbers of those following through on declared intentions is much smaller, as practical decisions are constrained by the difficulties of obtaining foreign visas, finding jobs, and other logistical issues. We need to bear in mind, also, that the outmigration is matched by the flow of immigrants entering Russia, usually less educated and mostly from the "near abroad" - the countries that were once part of the Soviet Union.

Key reasons for leaving the country identified by the Levada Center are poor living conditions, unstable economic circumstances, repressive government policies, and the desire to ensure a better future for one's children. Conversations with those who chose this path often bring up the issue of personal dignity. "I am tired of having my rights violated and my dignity ignored," goes the argument; "life is short, the problems of this world are intractable, the best I can do is to find a safe niche for myself and my family and savor whatever political, economic, cultural decencies are within reach.” Variations on these themes permeate the émigré discourse.

After Vladimir Nazarov lost control over his theater, his prospects for making a living dimmed. The role of a public intellectual exposed him to personal attacks, verbal and physical. So he moved to Ukraine where he put together a performance group. It is too early to say how successful his stagecraft will be in the new environs, but he is optimistic. Nazarov scoffs at his former colleagues like Oleg Tabakov who endorsed the Crimean adventure in exchange for personal safety and professional opportunity. Such a price is too high for a self-respecting person. Nazarov is concerned that the freedom to leave the country may be curtailed. He urges his friends to weigh the risks and make up their minds sooner rather than later where to live.

Actually, there is little evidence that the government wants to curtail emigration. The reverse seems to be the case, at least when it comes to dissidents. The outspoken critics are warned to depart or face prosecution. When this tactic fails, formal criminal investigations are launched to remind persistent opponents that the government is watching. This is how Pavel Pavlensky was driven out of the country. A performance artist known for his provocative presentations - he once set afire the entrance to the former KGB offices to symbolize its affinity with the gates of hell - Pavlensky found himself framed by the secret police who charged him as a sexual predator after a murky encounter that appeared to involve an informer acting in collusion with the authorities. Andrei Piontkovsky, a noted political scientist who promoted the 2010 liberal manifesto "Putin Must Go,” left Russia voluntarily after the federal investigative 
committee was about to charge him with "extremism” following the publication of an article where he suggested that Moscow pays tribute to Ramzan Kadyrov, leader of Chechnya, after failing to rein in the restive province by force. Pavlensky now lives in France, Piontkovsky in the United States.

Members of the Russian LGBT community are hard pressed to decamp from a country hostile to people of unconventional sexuality. In 2013, immediately after the parliament approved a statute prohibiting "gay propaganda," the authorities barred gay pride parades and clamped down on gay gatherings and publications. Two hundred forty-five Russian citizens applied for U.S. asylum between January and December of 2016, citing systematic discrimination based on their sexual orientation (American Questions, 2018). "I never dreamed of emigration,” confides Gleb Latnik, "until the ground started burning under my feet. The officials [from the Center for Combatting Extremism] threatened me with jail. I told them I didn't do anything unlawful, to which they replied, 'This is Russia, young man, you don't have to do anything illegal for us to find reasons to put you in jail.” (Latnik, 2016)

Not everyone is willing to wait till the government goes after you. Grigory Chkhartishvilli, a successful novelist writing under the pen name of Boris Akunin, left Russia because the country had changed so much in the last few years. "I have nothing in common with Putin's Russia. To stay in the country that lost its mind is unbearable. That doesn't mean I am emigrating, although I intend to spend most of my time abroad. A sober-minded person doesn't like to be locked in the same room with the drunkard. I'll come back to check the situation, to see if the hangover is over. Meanwhile, I'll remain 'part of Russia' - expatriation is not an option for me - and Russia inside me won't go anywhere either.” (Chkhartishsvilli-Akunin, 2014)

Most intellectuals unsatisfied with the present conditions chose to endure the repressive regime at home rather than face the uncertainties of emigration. Some lend their voices to the opposition, others take up small projects, still others retire into what the intellectuals of the bygone era called "internal emigration" - withdrawing from public affairs, taking up odd jobs, concentrating on one's family and friends.

Maria Eismont, journalist and humanitarian activist, acknowledges that fleeing the country may be a necessity for those engaged in opposition politics (Eismont, 2015). When the alternative is "either to go to jail or to leave the country," finding safe ground abroad is a prudent choice. Many of her friends secured permits to settle abroad in case the situation continued to deteriorate. Eismont thinks that personal safety risks are somewhat exaggerated by those who made up their minds about emigration and look to rationalize their decisions. Her family wellbeing is where she draws the line. "I have three children, and if I realize that they are no longer physically safe - that will be a tipping point for me. Otherwise, I’ll stay put.”

Liudmila Ulitskaya, a winner of literary awards and a soft-spoken intellectual unafraid to speak her mind, spends much time abroad. Still, she is unwilling to forgo her homeland permanently. Ulitskaya gestures toward the public space occupied by her fellow citizens, not necessarily openly opposed to the regime. "Many friends in my circle dedicate themselves to good deeds, that is where they find reason to persist. Children saved by Chulpan Khamatova, the 
first Moscow hospice organized by now-deceased Vera Millinshchikova, her daughter Newta Federmesser following in her mother's footprints - this is my sphere of meaning. I have many friends who not only save themselves but also create a life full of meaning around them." "As for myself,” Ulitskaia (2016) concludes, “I feel at home wherever I can get to my computer.”

Sergei Medvedev is professor of political science at the Advance School of Economics in Moscow. For several years, he was a research fellow at the European Center for Security Studies and then returned to Russia because he saw unmatched opportunities for collaborative work and personal fulfillment. He is ambivalent about the prospects of continuing work in Russia, however. "People keep asking me why I came back," Medvedev (2015) said in an interview. "My standard answer is that the quality of life for me is more than decent food, reliable gasoline for my car, fresh air, good roads and medical services - it is also the quality of communications and self-fulfillment. This is what I found in Russia during the last 10-11 years. But the humanitarian institutions have been folding up lately, the whole humanistic sphere is shrinking, and along with it the chance to realize oneself. The breakdown of communications has been staggering in the aftermath of Crimea. It isn't that I am thinking of emigration, although the thought has crossed my mind, but the two reasons why I live in Russia - communications and self-fulfillment - have been put to a serious test.”

Maria Baronova is a political activist and key figure in the "Open Russia” movement sponsored by Mikhail Khodorskovsky, émigré businessman who spent 10 years in penal colony on trumped-up charges. Baranova sought to become a parliament member, attended numerous unauthorized meetings and was repeatedly arrested by the police. Her chief concern with present-day Russia is that the country is losing its talented people to the West and becoming more and more parochial. "The fear that Russia would fall behind other nations has always haunted the Russian intelligentsia. Common folks saw Russia’s greatness in its might, the intelligentsia saw its future as a progressive nation, and now all are losing their hope” (Baronova, 2017). Last June, after yet another scuffle with the police, Baronova quit politics, explaining her decision in a Facebook post: "I woke up one day and asked myself, 'Barrymoore, do you really want to sacrifice your life for something nobody cares for'? I just want to live. Live here and now. Sometimes one craves not just a chance to battle the police, waste time in courts, scramble for resources to build civil society, or spend meaningless hours in the investigative committee. Sometime one simply wants to rest.”

After the assassination of Caesar, the situation in Rome deteriorated rapidly. With civil war looming, Cicero had to choose sides in the deadly struggle. He threw his lot with the senatorial party of optimates, which placed him on a collision course with Mark Antony and his minions. The Philippics he delivered against the strongman failed to reach their goal - the senate declined to declare Antony an enemy of the state. Now Cicero found himself in mortal danger. A massive manhunt got underway after the new powers proscribed the champion of republican virtues. Cicero scrambled to safety in neighboring Macedonia, but crucial time was lost. On December 7, 43 B.C.E., Antony's henchmen caught up with Cicero at his villa in Formiae and killed the foremost public intellectual of this era. According to Cassius Dio, Cicero's severed head and hands were displayed in the public forum where Antony's wife Fulvia repeatedly pierced with her hairpin the orator's tongue, the hated symbol of free speech. 
As all historic analogies, this one breaks down if pushed too far. And yet, Putin's increasingly autocratic habits raise the question of where his brand of caesarism leads. The list of Putin's opponents who have met violent deaths is getting longer. Galina Starovoitova, the Russian parliamentarian who pressed for a law barring former KGB agents from high office, was murdered four months after Putin assumed power as head of the KGB successor agency. Political assassinations have punctuated Putin's presidency, claiming the lives of former secret agent Aleksandr Litvinenko, Forbes correspondent Pavel Khlebnikov, human rights activist Natalia Estimirova, investigative journalist Anna Politkovskaya, civil rights attorney Stanislav Markelov, former deputy prime minister Boris Nemtsov. As the Memorial Foundation adds names to the roster of prisoners of conscience, people incurring Putin's displeasure disappear or die under suspicious circumstances.

Another analogy comes to mind when you think about the upsurge of nationalism following Russia's geopolitical collapse in the 1990s - the Weimar Republic and the rise of German nationalism. Demoralized by the outcome of World War One, Germans endured an extended period of national malaise, looking for scapegoats and pining for ways to avenge the humiliation of the Treaty of Versailles. Their prayers appeared to have been answered when Adolf Hitler and the national socialists came to power. The Nazi regime united the divided country, raised the economy from ruin, and rebuilt the military. It also dismantled civil liberties, banned opposition parties, and after securing support of leading intellectuals like Carl Schmitt and Martin Heidegger embarked on the campaign to reclaim the lost territories and vanquish its European enemies. This great national awakening and World War II that followed proved to be even more disastrous for Germany than the previous world war.

To be sure, Putin is no Hitler, or else we wouldn’t hear from his liberal critics inside Russia. But look at the poll the Levada Center conducted in April of 2017 (Levada Center, 2017) - 38\% of the Russians weaned on state propaganda pronounced Joseph Stalin the greatest world leader of all time, with Vladimir Putin close second (34\%). Only 12\% of the Russians welcome liberalization in their country. Now, consider the rising tide of militant nationalism, the creation of national guards answerable to one man, the steady erosion of constitutional rights, the violent suppression of public protests, the deployment of street thugs to intimidate the opponents, and you may wonder if xenophobic forces unleashed by Putin bode well for Russia's future.

I want to close this essay with an excerpt from the dialogues I've carried out over the years with Dr. Vladmir Yadov. Dean of Russian sociologists, president of the National Sociological Society, director of the Institute of Sociology, this eminent sociologist was a keen observer of the Russian political and intellectual scene. Yadov, who died two years ago, was reluctant to publicize his views while he was alive. Now that parts of our exchanges have been made public, courtesy of the Levada Center, it seems fitting to share Yadov's observation that sums up his, mine, and many of our colleagues’ attitude toward present-day Russia:

The trends in our part of the world are mixed, with three main vectors predominating: a powerful current of imperial nationalism, a pitiful trickle of liberalism, and a mounting wave of fascism. The first and the third trends may well merge in the future. The driving force behind the emerging structures of "national 
democracy” is Vladimir Putin... Toward Putin I feel nothing but loathing. A cruel and cynical man who craves power and feels contempt for his people, he longs for wealth and luxury. What did he say when asked about liberal politicians? He said, 'All they want is power and money!' Yet his personal wealth is ensured by his control over the oil pipeline. No doubt, this man can blackmail every single person in his entourage, including [Dmitri] Medvedev. You can imagine how much scorn will be poured on this man 30 years from now. (Shalin, 2015, p. 217)

*This essay is based in part on the databases assembled by the UNLV Center for Democratic Culture. The "International Biography Initiative" and "Russian Culture" projects feature conversations with Russian intellectuals, highlighting the cost of being a public intellectual in a country where democratic institutions are moribund and the state is indifferent to human dignity. 


\section{References}

American Questions. 2016. Rekordnoe chislo rossian v 2017 g. poprosili ubezhishia v SShA. [Record number of applicants from Russia applied in 2017 for an asylum in the USA]. Radio Liberty. May 3, 2018, https://www.svoboda.org/a/29206320.html.

Baronova, Maria. 2017. 'Zhit ochen khochetsia': Maria Baronova ukhodit iz oppozitsii ['I just want to live': Maria Baronova leaves the opposition movement]. June 14, http://www.mk.ru/politics/2017/06/14/zhit-ochen-khochetsya-mariya-baronova-ukhoditiz-oppozicii.html.

Brodsky, Joseph. 1994. Na nezavisimost Ukrainy [On the Ukrainian independence]. World Art, http://www.world-art.ru/lyric/lyric.php?id=7886.

Chkhartishsvilli-Akunin, Boris. 2014. V subbotu, den nenastnyi [Once upon a rainy Saturday]. Boris Akunin’s Blog. August 30, https://borisakunin.livejournal.com/135653.html.

Cicero, Marcus Tullius. 49B.C.E./1913. Letters to Atticus, vol. 2. Cambridge, M.A.: Harvard University Press.

Dondurei, Daniil. 2012. Interview. Echo of Moscow. December 5, https://echo.msk.ru/programs/personalno/961718-echo.

Eismont, Maria. 2015. Uezzhat ili ostatsia? [To emigrate or to stay?]. Radio Liberty. June 17, https://www.svoboda.org/a/27077566.html.

Emigratsionnye nastroenia. 2015. Zapad: vospriiatie i stremlenie emigrirovat [West: the perception and emigration mood], Levada Center, June19.

http://www.levada.ru/2015/10/13/zapad-vospriyatie-i-stremlenie-emigrirovat.

Kochetkova, Inna. 2010. The myth of the Russian intelligentsia. Old intellectuals in the new Russia. New York: Routledge.

Kollektivnoe obrashchenie. 2014. Deiateli kultury Rossii: v podderzhku pezidenta po Ukraine I Krymu [Russian culture workers voice their support of the President's policies in Ukraine and Crimea]. March 11, https://www.mkrf.ru/press/news/deyateli-kultury-rossii-vpodderzhku-pozitsii-prezidenta-po-ukraine-i-krymu20171009103201.

Konchalovsky, Andrei. 2016. Nelzia vo glavu ugla stavit prava cheloveka ['It is hubris to treat human rights as a paramount value.’: Interview with Andrei Konchalovsky]. Meduza. October 26, https://meduza.io/feature/2016/12/26/nelzya-vo-glavu-ugla-stavit-pravacheloveka.

Latnik, Gleb. 2016. Eto pervyj veterok bolshoi grozy [First signs of the pending storm.] Radio Liberty. November 1, https://www.svoboda.org/a/27337714.html. 
Levada Center. 2014. Attitudes toward emigration. Press release. June 6, http://www.levada.ru/2014/06/05/emigratsionnye-nastroeniya.

Levada Center. 2015, Attitudes toward emigration. Press release. October 13, http://www.levada.ru/2015/10/13/zapad-vospriyatie-i-stremlenie-emigrirovat.

Levada Center. 2016. Attitudes toward emigration. Press release. July 19, http://www.levada.ru/2015/10/13/zapad-vospriyatie-i-stremlenie-emigrirovat.

Levada Center. 2017. Attitudes toward emigration. Press release. June 19, http://www.levada.ru/2017/06/19/emigratsionnye-nastroeniya-2.

Medvedev, Sergei. 2017. Iskusstvo kompromisa [The art of compromise]. Radio Liberty. September 23, https://www.svoboda.org/a/27267256.html.

Moritz, Yunna. 2014. Yunna Motiz ob Ukraine i rusofobii ['My Ukraine is different: Interview with Yunna Moritz’]. December 1, Liveinternet.ru, https://www.liveinternet.ru/users/wildwesttx/post345202019.

Nazarov, Vladimir. 2015. Staryi muzykant, kotoromu nadoelo boiatsia [The old musician who is tired to be scared]. Radio Liberty. December 26, https://www.svoboda.org/a/27450814.html.

Novodvorskaya, Valeria. 2014. Vina s pechaliu popolam. [Our guilt and sadness sorry mix] Grani.ru. March 28, https://graniru.org/opinion/novodvorskaya/m.227183.html.

Obrashchenie initsiativnoi gruppy, 2014. Obrashchenie initsiativnoi gruppy po provedeniiu Kongessa intelligentsii 'Protiv voiny, protiv samoizolatsii Rossii' [The intelligentsia activists against the war, self-isolation, and return to totalitarism in Russia. Novaia gazeta. March 12, https://www.novayagazeta.ru/news/2014/03/13/97897-obraschenieinitsiativnoy-gruppy-po-provedeniyu-kongressa-intelligentsii-171-protiv-voyny-protivsamoizolyatsii-rossii-protiv-restavratsii-totalitarizma-187-i-pismo-deyateley-kultury-vpodderzhku-pozitsii-vladimira-putina-po-ukraine-i-krymu.

Rein, Evgeny. 2015. Broskogo ia nazyval 'V bagrets i zoloto odetaia lisa [I called him 'a fox in the golden robe'] Radio Liberty. May 23, http://www.svoboda.org/articleprintview/27028746.html.

Shalin, Dmitri. 1989. Settling Old Accounts. Christian Science Monitor. Friday, December 29, https://www.csmonitor.com/1989/1229/eshal.html.

Shalin, Dmitri 1990. Ethics of Survival. Christian Science Monitor. Tuesday, December 4, https://www.csmonitor.com/1990/1204/eshal.html. 
Shalin, Dmitri. Emotional Barriers to Democracy Are Daunting. Los Angeles Times, 1993, Wednesday, October 27, http://articles.latimes.com/1993-10-27/local/me50060_1_emotional-intelligence.

Shalin, Dmitri. 1996a. Intellectual Culture, Pp. 41-98 in Russian Culture at the Crossroads: Paradoxes of Postcommunist Consciousness. Ed. by D. N. Shalin. Boulder: Westview Press.

Shalin, Dmitri, 1996b. Soviet Civilization and Its Emotional Discontents. International Journal of Sociology and Social Policy 16:21-52.

Shalin, Dmitri. 2015. Iz dialogov Vladimira Yadova Dmitria Shalina. [From dialogues of Vladimir Yadov and Dmitri Shalin.] Public Opinion Monitor, No. 3-4, pp. 194-219, http://cdclv.unlv.edu/archives/articles/vy_ds_dialogues.pdf.

Shenderovich, Viktor. 2017.Tsitata iz Grigoria Pomerantsa [A quote from Gregory Pomeranz.] Echo of Moscow. June 20, https://echo.msk.ru/blog/shenderovich/2003794-echo.

Tabakov, Oleg. 2015. Tabakov ob ukraintsakh: oni v kakom-to smysle ubogie [Tabakov about Ukrainians: 'They are pathetic in some sense']. Gordonia.com. July 10, http://gordonua.com/news/worldnews/tabakov-ob-ukraincah-oni-v-kakom-to-smysleubogie-ih-luchshie-predstaviteli-vsegda-byli-na-vtoroy-ili-tretey-pozicii-posle-russkih88990.html.

Tolstaya, Tatiana. 2017. Interviu s Kritinoi Khudenko [Interview with Kristina Khudenko.] Echo of Moscow. January 25, https://echo.msk.ru/blog/echomsk/1916212-echo.

Ulitskaia, Liudmila. 2016. Zadachi sionizma vypolneny [Zionism has accomplished its goal.] Radio Liberty. August 14, https://relevantinfo.co.il/ulitskaya-sionism.

Yadov, Vladimir. 2011. Skvernaia istroria [Bad story.] Troitsky Perspective. December 6, http://trv-science.ru/2011/12/06/skvernaya-istoriya. 